\title{
Cultural-Based Alternative Assessment Development in Elementary School Mathematics
}

\author{
Sukmawarti* and Hidayat \\ Universitas Muslim Nusantara Al Washliyah Medan, Indonesia \\ *Corresponding author email: sukmawarti@umnaw.ac.id
}

\begin{abstract}
Assessment is an integral part o curriculum. Mathematics assessment is a mathematics learning tool that is useful for teachers as a reflection and to determine the competence of their students. However, the assessment applied by the teacher is still not in accordance with what has been tested or standardized. The measurement of student competence is still focused on the aspects of knowledge. The purpose of this research was to design an alternative assessment model based on culture in elementary school mathematics learning. This type of research is the development research of the Borg and Gall model, through the Define, Design, and Develop stages. This stage begins with analyzing the 2013 curriculum, analyzing basic competencies, and analyzing cultural values. Furthermore, designing an alternative assessment draft and validating it to experts, so that it becomes an alternative assessment model based on culture in elementary mathematics learning. The resulting mathematics alternative assessment has proven its validity in terms of material, language, and presentation, with a very good category.
\end{abstract}

Keywords: Alternative Assessment, Culture, Elementary Mathematics

\section{INTRODUCTION}

Development of the 2013 Curriculum is a further step towards Competency-Based Curriculum Development which was initiated in 2004 and KTSP 2006, which emphasizes the attainment of competency attitudes, knowledge, and skills in an integrated manner [1]-[4].

The 2011 TIMSS analysis of more than $95 \%$ of Indonesian students was only able to reach the intermediate level. Students tend to be interested only in routine questions that are directly related to formulas. The assessment given to students is not in accordance with what was tested or standardized [5].

The problems mentioned above were triggered by the assessment mechanism implemented. A common phenomenon is the assessment process that is separate from learning and tends to be traditional. In traditional assessments, students are usually given memorizing and calculating questions in mathematics, both during lessons, exercises, homework, and semester exams. This indicates that the assessment carried out has not fully measured the three aspects of knowledge, attitudes, and skills, as mandated by the 2013 curriculum. Traditional assessment methods for measuring achievement, such as multiplechoice tests, true/false, matchmaking, etc. have failed to determine performance students [6].

Another cause is the assessment techniques and the types of instruments given to students. Inaccuracy of the technique and type of instrument with the aspects being measured will obscure the measurement results [7]-[10]. In general, the assessments applied in schools have not yet fully measured the aspects of knowledge, attitudes and skills in an integrated manner as mandated by the 2013 curriculum. Assessment tends to be traditional, such as tests failing to find out students' real performance. The assessment techniques and types of instruments were also inaccurate. This can be a misinterpretation of the achievement of student competencies. Such assessments have failed to obtain a complete picture of attitudes, skills and knowledge. Therefore, it is necessary to apply alternative assessments, which can measure the attainment of knowledge and skills as a whole and integrated with attitudinal competences and can identify the realization of cultural values. Cultural-based attitude values need to be 
instilled from the early age of school, because attitude characters can be formed through imitation and habituation. The inculcation of these attitude values can be integrated into the assessment process. For this reason, it is necessary to design an alternative assessment model based on culture in elementary school mathematics (SD). The research problem in this research, namely how to develop a valid culture-based alternative assessment model in elementary school mathematics.

\section{METHODOLOGY}

This research is a developmental research, which is research oriented towards the development of culturebased mathematical assessment tools. The product produced in this research is a culture-based alternative assessment model for elementary school mathematics.
The development model used is the Borg and Gall model [11]-[13]. In this research an alternative assessment model will be developed, in collaboration with experts who are competent in the field of learning evaluation.

Existing mathematics education research is generally more focused on the classroom. However, there are new findings that show that a lot of mathematics knowledge can also be obtained outside of school, one of them is findings about ethnomathematics [14]. Students develop representations and procedures into their cognitive system, which is a process that occurs in the context of social activities that are built. In other words, students' mathematics learning abilities are not logically built on abstract cognitive structures but forged from a combination of previously acquired knowledge and new cultural skills and inputs.

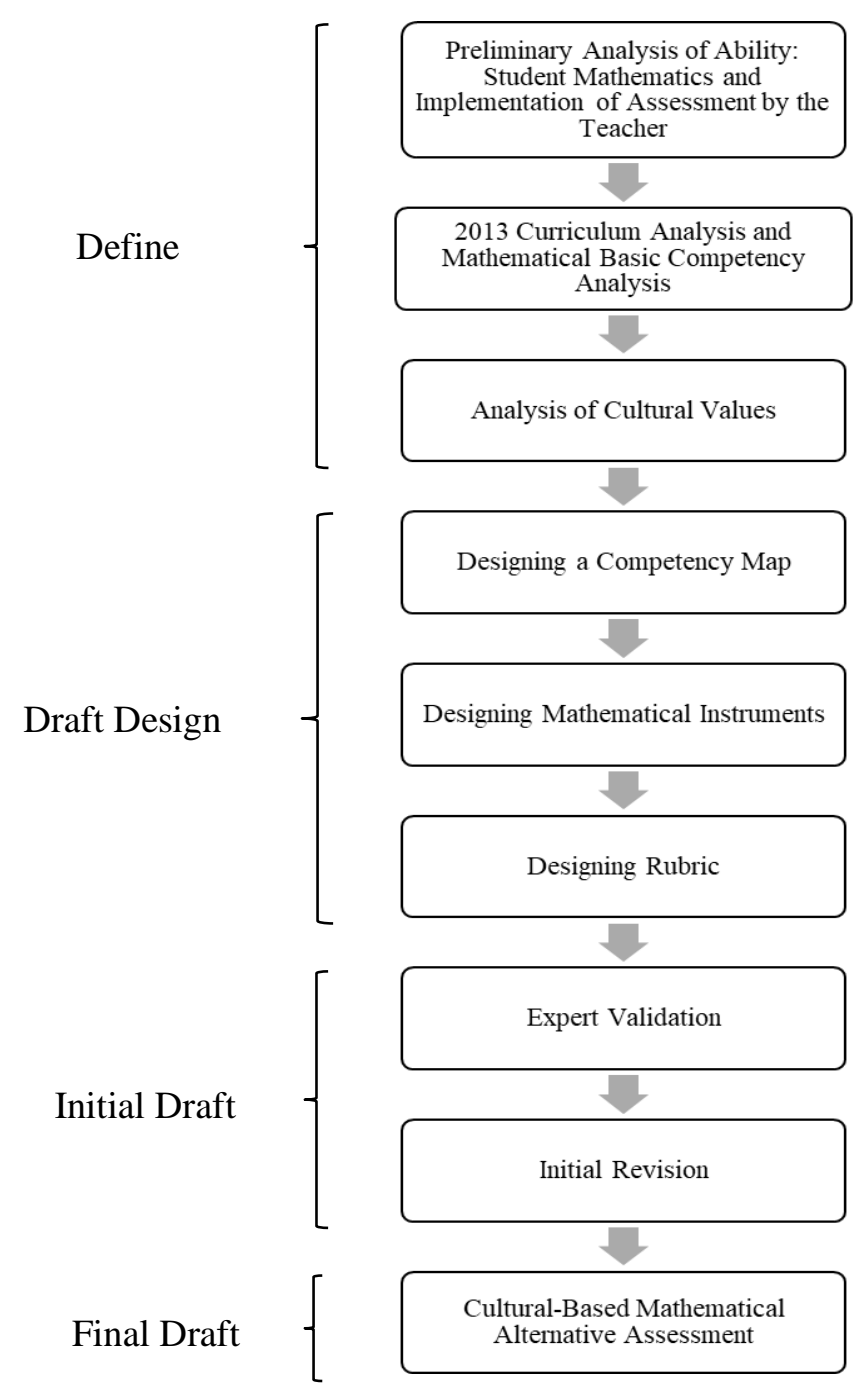

Figure 1 Research Design 
Humans not only as social beings produce systems of thought, values, morals, norms, and beliefs, but also, in interactions with fellow humans and the realm of life, humans are governed by the system of thinking, values, morals, norms, and beliefs that have been produced.

On this basis, the development of culture and character education is very strategic for the sustainability and excellence of the nation in the future. This development must be done through good planning, appropriate approaches, and effective learning and learning methods. In accordance with the nature of a value, cultural education and national character are joint efforts of schools. Therefore, it must be carried out by all teachers and school leaders, through all subjects, and become an inseparable part of the school culture.

Based on the results of research on the ethnomathematical form of Lampung people, which is reflected in the various results of mathematical activities that are owned and developed in the community, including mathematical concepts [15].

\section{RESULTS AND DISCUSSION}

The results achieved in research in the first year in accordance with the activities carried out are summarized in Table 1.

One culture that can be integrated in the assessment activity is Gordang Sambilan. Gordang Sambilan is one of the cultural products of Mandailing North Sumatra, which is a musical instrument [16]. Gordang Sambilan has been used as a musical instrument for traditional arts for various traditions such as marriage. The following is a picture of Gordang Sambilan musical instrument.

Table 1 Results Achieved

\begin{tabular}{lll}
\hline Stages & \multicolumn{1}{c}{ Type of Activity } & \multicolumn{1}{c}{ The Results Achieved } \\
\hline Stage-I & Analysing the curriculum & Elementary mathematics competence \\
(Define) & Determine elementary students' math abilities & Formulation of elementary students' math abilities \\
\hline Stage-II & Create a competency map & Mathematical competency map \\
(Design) & Determine the assessment task & Alternative assessment assignments \\
& Create an assessment instrument & Alternative assessment instrument \\
& Create a rubric & Assessment rubric \\
\hline
\end{tabular}

Table 2 Assessment Map Gordang Sambilan

\begin{tabular}{ll}
\hline \multicolumn{1}{c}{ Aspect } & \multicolumn{1}{c}{ Mathematics Learning Objectives } \\
\hline Attitude & Having an attitude of appreciating the usefulness of mathematics in life, namely having curiosity or concern. \\
Knowledge & Linking various concepts in mathematics and outside mathematics. \\
Skills & Using patterns in problem solving. \\
\hline
\end{tabular}

Instrument

Based on the description of the Gordang Sambilan, determine:

1. the size of the diameter and height of each Gordang eneng-eneng, tepe-tepe, kudong-kudong, paniga, and jangat;

2. comparison of the diameter and height of the smallest Gordang with the largest;

3. the volume of each of the Gordang Sambilan; and

4. the volume ratio of each of these Gordang Sambilan.

Gordang Sambilan consists of nine drums that have different heights and diameters. The smallest drum is 20 $\mathrm{cm}$ in diameter, so the bigger the drum the diameter increases by $5 \mathrm{~cm}$, so that the largest drum is $60 \mathrm{~cm}$ in diameter. Likewise, the height of the drum from the smallest drum is about $120 \mathrm{~cm}$ to $160 \mathrm{~cm}$ in height. The difference in the size of the diameter and the height of the Gordang results in variations in sound that more or less similar to differences in scale. In addition to the differences in size mentioned above, differences in sound can also be generated with tightness. The pull of the rattan rope is tied to the leather membrane. Gordang Sambilan curtain is made of wood which is perforated at one end of the hole, then the other end is closed using a membrane made of cowhide.
The skin is tightened using rattan, which also functions as a binder. To sound a wooden bat is needed, with the smallest tones of the drum as eneng-eneng, drums 2 tepetepe, drums 3 and 4 kudong-kudong, drums 5 and 6 paniga, and drums 7, 8, and 9 as jangat. In practice, Gordang Sambilan game is accompanied by two gongs, three small gongs called mongmongan, one medium gong is called a doal, a pair of small cymbals (sasayat ropes), and accompanied by a wind instrument called saleot. In playing it, it usually starts with a doal sound three times, greeted with the sound of mongmongan dangong which all consists of pukullogam musical instruments. After that, udong-kudong and paniga are sounded, followed by tepetepe and eneng eneng. After all the sound elements are 
united then beaten by the sound of hides as a regulator of rhythm [17].

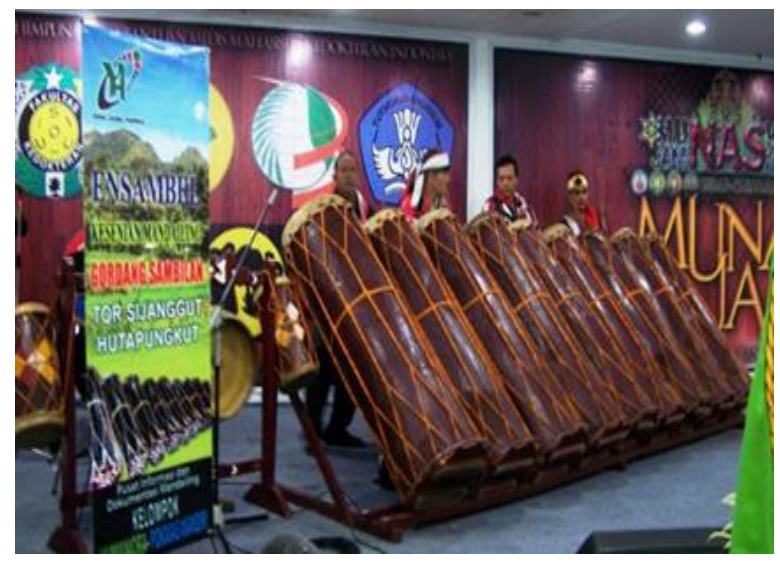

Figure 2 Gordang Sambilan in Mandailing Natal

From this cultural context, an assessment instrument can be developed, both aspects of knowledge, skills, and attitudes. An assessment map that can be developed from the Gordang Sambilan culture, is formulated in Table 2.

Mathematical instruments that have been compiled, before use, are validated by 2 validators who are competent in the fields of mathematics education and social anthropology.

The results of the assessment from the validator show that the total score of the assessment is 97 in very good categories. Based on the results of this assessment, the mathematical instruments arranged have met the requirements as an assessment tool in learning mathematics. This assessment tool can be directed at developing mathematical skills, including: (1) using mathematical connections between various mathematical ideas, (2) understanding how mathematical ideas are related to one another so that a comprehensive understanding is built, and (3) using mathematics in context outside of mathematics.

\section{CONCLUSION}

Based on the results of research and discussion, it can be concluded that culture-based alternative assessment in elementary school mathematics can be developed by analyzing elementary school (SD) mathematics competence and linking cultural outcomes with mathematical concepts, as well as paying attention to mathematics learning objectives. The culture-based elementary school (SD) alternative mathematics assessment developed has been valid and feasible to use. Based on the above conclusions, it is suggested that elementary school (SD) teachers be able to develop alternative assessments in mathematics learning by integrating it with cultural values.

\section{REFERENCES}

[1] I. Gunawan, Indonesian Curriculum 2013: Instructional Management, Obstacles Faced by Teachers in Implementation and the Way Forward. 3rd International Conference on Education and Training (ICET 2017), Advances in Social Science, Education and Humanities Research, 128 (2017), 56-63.

[2] S. Yuliani, Teaching Activity by Implementing Curriculum 2013 at SMP Negeri 23 Pekanbaru. JSHMIC: Journal of English for Academic, 4 (2) (2017), 94-100.

[3] D. Mitra, P. Purnawarman, Teachers' Perception Related to the Implementation of Curriculum 2013. Indonesian Journal of Curriculum and Educational Technology Studies, 7 (1) (2019), 44-52.

[4] M. S. Fauzi, Implementation of Curriculum 2013 for Physical Education, Sport and Health of Junior Highschool in Samarinda. Acitya: Journal of Teaching \& Education, 1 (2) (2019), 131-141.

[5] H. Retnawati, S. Hadi, A. C. Nugraha, Vocational High School Teachers' Difficulties in Implementing the Assessment in Curriculum 2013 in Yogyakarta Province of Indonesia. International Journal of Instruction, 9 (1) (2016), 33-48.

[6] G. Wiggins, Assessment: Authenticity, context and validity. Phi Delta Kappan, 75 (3) (1993), 200-214.

[7] E. T. Amua-Sekyi, Assessment, Student Learning and Classroom Practice: A Review. Journal of Education and Practice, 7 (21) (2016), 1-6.

[8] Ismail, I. Astuti, A. Mering, Evaluation of Learning Outcome Assessment System in Health and Sports Physical Education Subject in Junior High School. Journal of Education, Teaching and Learning, 3 (2) (2018), 296-301.

[9] V. Wahyuni, Kartono, E. Susiloningsih, Development of Project Assessment Instruments to Assess Mathematical Problem-Solving Skills on A Project-Based Learning. Journal of Educational Research and Evaluation, 7 (2) (2018), 147-153.

[10] O. Rosfiani, M. Akbar, A. Neolaka, Assessing Student Social Studies Learning: Effects of Learning Environment, Inquiry, and Student Learning Interest. TARBIYA: Journal of Education in Muslim Society, 6 (1) (2019), 46-57. 
[11] W. R. Borg, M. D. Gall, Educational Research: An Introduction, Fifth Edition. New York: Longman, 1989.

[12] A. Suyatna, H, Maulinam I. Rakhmawati, R. A. N. Khasanah, Electronic Versus Printed Book: A Comparison Study on The Effectivity of Senior High School Physics Book. Jurnal Pendidikan IPA Indonesia, 7 (4) (2018), 391-398.

[13] A. Muhardi, B. S. Anwar, C. K. Rukun, D. Jasrial, Learning Model Development Using Moodle ELearning Software by Implementing Borg and Gall Method. 3rd International Conferences on Information Technology and Business (ICITB), 7th December, (2017), 167-176.

[14] A. Kusaeri, H. H. Pardi, A. Quddus, Culture and mathematics learning: Identifying students'mathematics connection. Beta: Jurnal Tadris Matematika, 12 (1) (2019), 82-93.

[15] Badan Penelitian dan Pengembangan Kementrian Pendidikan Nasional, Pedoman Pendidikan Budaya dan Karakter Bangsa. Jakarta: Kemendiknas, 2010.

[16] E. Nasution, Tulila: Muzik Bujukan Mandailing. Areca Books, 2007.

[17] M. B. Parinduri, Ensambel Gordang Sambilan. Medan: Pusaka Mandailing, 2016. 